\title{
Investigating the Relationship between Iranian Undergraduate TEFL Learners' Self-regulation and Self-efficacy
}

\section{Zeynab Yazdizadeh ${ }^{1}$, Goodarz Shakibaei ${ }^{1 *}$, \& Ehsan Namaziandost ${ }^{2}$}

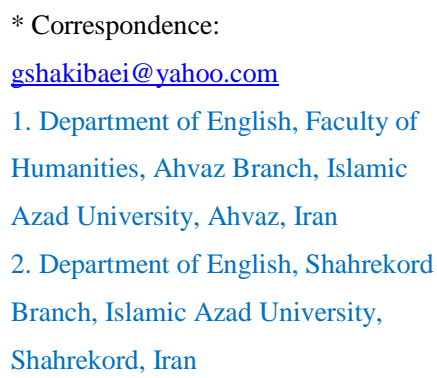

Received: 24 October 2019

Revision: 22 January 2020

Accepted: 31 January 2020

Published online: 20 September 2020

\begin{abstract}
The present empirical study investigated the relationship between Iranian undergraduate TEFL learners' self-regulation and their self-efficacy. For this end, there have been a total number of 120 college students learning English as a foreign language who volunteered to complete the two quantitative questionnaires of self-regulation and self-efficacy respectively. The participants were informed of the anonymous nature of the data collection process in advance. They were also told that their responses would certainly be kept confidential and that they had the right to quit at any part of the survey. It took around 15-20 minutes for each respondent to complete the survey. In the meanwhile, some of the participants (around ten) also willingly answered the qualitative descriptive semi-structured questions of the interview, until that the interview responses were saturated. After the process of data collection, the findings were measured through correlation analysis, indicating that self-regulation and self-efficacy were jointly linked and had a directly positive relationship. Accordingly, it was revealed that the employment of these two highly associated psychological constructs could systematically guide and help learners to enhance their learning capabilities and lead them to ultimate desired learning goals. Ultimately, it was concluded from the findings of the current study that the delicate association between self-regulation and self-efficacy was really helpful for learners to lead them successfully to their academic goals.
\end{abstract}

Keywords: academic goals, psychological constructs, $\underline{\text { self-regulation, self- }}$ efficacy, quantitative questionnaire 


\section{Introduction}

Self-regulation and self-efficacy are increasingly important in foreign language learning. In fact, both of them have recently become widely accepted as the two significant phenomenal themes of study in the modern time psychoeducational sciences. Self-regulation and self-efficacy indeed enable language learners to facilitate language learning opportunities beyond the traditional language learning acquisitions and methodologies. According to Zimmerman (2000), self-efficacy is mentally and psychologically different from other areas of study. Self-efficacy includes such determining beliefs and intellectuals which are exclusively unique for individual learners. Moreover, self-efficacy is very acute to impalpable changes in the behavior of the students, and in correlation with self-regulated learning strategies and processes. Self-efficacy indeed specifies learners' performance at definite levels. Beforehand, Bandura (1986) had already remarked the great difference among self-efficacy and predictions of educational achievements.

Bandura (1993) believed that in fact self-efficacy was the belief about the specific abilities of learning that could help learners with their learning behaviors. Such beliefs indeed could identify and direct learners' emotions, conceptualizations, self-motivations, and learning behaviors. Based on the cognition, motivation, affection, and selection procedures, self-efficacy might have different results for each learner. According to Pajares and Usher (2008), "all of the thoughts that affect human functioning, and standing at the very core of social cognitive theory, are self-efficacy beliefs, which can be defined as the judgments that individuals hold about their capabilities to learn or perform courses of action at designated levels" (pp. 395-396).

Bandura (1997) also illuminated that self-efficacy was fundamentally based on a greater structure, the social cognitive hypothesizing that performance, attitudes, and context of learners significantly determined their learning progress. Moreover, self-efficacy could be helpful for learners in terms of activity, determination, flexibility, and progress. Learners with a powerful self-efficacy would tend more to be well-prepared to participate in leaning activities, and to administer learning process more efficiently and consciously so that they could reach their ultimate intelligently designed goals as well. Zeidner, Boekaerts, and Pintrich (2000) explained that "Self-efficacy is a subset of selfregulation which also is a systematic process of human behavior" (p. 751). Zimmerman and Cleary (2006) and Aghajani (2018) added that self-regulation practically follows three steps in the learning process: prediction, function, and self-evaluation. Actually, self-efficacy is more concerned with predictions of performance before learning. Learners with high self-efficacy manage to go through obstacles and move on to successfully attain preset learning goals (Niloufari \& Dastgoshadeh, 2019; Pajares, 2009), and they indeed tend more to apply self-regulation strategies and processes for learning English language (Anam \& Stracke, 2016).

According to Boekaerts and Cascallar (2006), self-regulation permanently regulates and monitors learning process of learners by setting goals, strategies use, and self-evaluate the process. Self-regulation also deals with multimotivational strategies involving: physical and mental preparation to perform the tasks, gathering the related data, blending the appropriate approaches, observing the understanding of learners, and finally evaluating their extent of development. On the same account, Zimmerman (1989) believed that "For students to be self-regulated, their learning must "involve the use of specified strategies to achieve academic goals on the basis of self-efficacy perceptions" (p. 329). Similarly, Schunk and Meece (2006) suggested that one's behavioral and environmental personal factors will enhance his or her expectations of success in challenging tasks situations.

Self-regulation and self-efficacy are totally associated variables on the account that self-efficacy is well-known to be a subcategory of self-regulation. In other words, self-regulation precedes self-efficacy in the way that learners with a powerful self-regulation have potentially a strong self-efficacy. Self-regulation is indeed the reflection of learners' strategies use and sufficient efforts towards better educational achievement and progress; in this way, self-regulation actually regulates, controls, and reforms learning processes, attitudes and approaches of learning, and substitute them with better applicable approaches for the aim of leading to desirable results (Namaziandost, Pourhosein Gilakjani, \& Hidayatullah, 2020).

\subsection{Statement of the Problem}

Thanks to the advancement of information technology, learning a second or foreign language has become undoubtedly indispensable for communication in the modern time. Needless to say, that despite all the language centers and English language learning materials in the global market, yet there would be a large number of students who fail to learn another language satisfactorily and gladly. That may be, in many cases, due to the lack of their beliefs in their abilities 
to learn any other languages, and their insufficient strategies to regulate and control their learning. Furthermore, due to the fact that language learning institutes (LLI) are highly time-consuming and money-taking, a lot of language learners would not willingly want to enroll and take part in such institutes. Instead, they would rather choose to study autonomously and totally independent from any LLI. However, whether it is a case of group-study or self-study, both self-efficacy and self-regulatory language learning are indeed inevitably predominant especially when they come in relation to each other.

\subsection{Research Questions}

This study tried to answer the following research questions:

RQ1. Is there a significant relationship between Iranian undergraduate TEFL learners' self-regulation and their selfefficacy?

RQ2. What predictive role does Iranian undergraduate TEFL learners' self-regulation play on their self-efficacy?

\subsection{Null Hypothesis}

Based on the above-mentioned questions, the following directional hypothesis was formulated in this study:

H1. There is a positive relationship between self-regulation and self-efficacy of Iranian undergraduate TEFL Learners.

\section{Review of the Literature}

\subsection{Theoretical Background}

Generally, recent researchers have tended to study self-regulation of learners (Zimmerman \& Schunk, 1989). Zimmerman (1990) signified that self-regulation was highly a matter of metacognitive, motivational, and behavioral manners of learners' learning process. Moreover, self-regulated learners were recognizable according to their selforientation, self-evaluation, and self-motivation (Zimmerman, Bandura, \& Martinez-Pons, 1992). Bandura (1991) explained that self-regulated learners were more likely to set challenging goals for themselves to speed up their learning processes and achievement. They also tended to apply much suitable strategies and more efficient choices of activities to attain to their goals. Finally, they were able to appropriately distinguish and categorize guidelines and expressions of self-regulation to accelerate process of learning through high motivation and increased efforts (Namaziandost, Nasri, \& Ziafar, 2019).

Further, Bandura (1997) enlightened that self-efficacy would significantly affect educational motivation in terms of amount of endeavor, continuity, and sentimental interactions. Learners with high extent of self-efficacy take part in the challenging tasks more readily, try harder, resist for a long period of time. They also show less opposite emotional reactions when they encounter difficulties than do those who doubt their capabilities. Self-efficacious learners were proven to have more commitments to challenging tasks. Self-regulated learners exhibit a high sense of efficacy in their capabilities, which influences the knowledge and skill goals they set for themselves and their commitment to fulfill these challenges (Namaziandost, Rezvani, \& Polemikou, 2020; Zimmerman, 1990). This conception of selfdirected learning not only encompasses the cognitive skills emphasized by metacognitive theorists, but also extends beyond to include the self-regulation of motivation, the learning environment, and social supports for selfdirectedness.

Dörnyei and Ryan (2015) have recently found that the significant factor which made learners individually different in learning language processes was their exclusive self-regulatory learning strategies use. To this end, self-regulation has captured the attraction of today researchers. They also believed that learners had their discrete capacity of selfregulation as an important element of successful language learning. According to Zimmerman and Schunk (2011), self-regulation studies were extremely important especially in the psychoeducational fields. Zimmerman and Risemberg (1997) clarified that the core focus of self-regulation was "the learners' own strategic efforts to manage their own achievement through specific beliefs and processes" (p.105).

Prior researchers unitedly agreed on the significant role of self-regulation for the development of motivational purposes and learning progress (Dignath, Büttner, \& Langfeldt, 2008; Namaziandost, \& Çakmak, 2020). Moreover, D€ornyei (2005) predicted that self-regulated learning would be certainly one of the most challenging themes of future studies. Particularly, several researchers have focused on the effective impression of technology on self-regulated learning processes and strategies used (Hashemifardnia, Namaziandost, \& Shafiee, 2018; Lam, 2014; Liu, Lan, \& Ho, 
2014; Ziegler, 2014; Ziegler \& Moeller, 2012). Theoretical research has been recently concentrated on the conceptual language learning skills of learners (Bandura, 1982). The theories were mostly around the capabilities and willingness of learners to learn English language independently (Etemadfar, Namaziandost, \& Banari, 2019; Schunk, 1984). On this view, self-regulation was different for various learners with different language learning skills, and progress of self-regulation in the learning process was overwhelming (Dörnyei \& Ryan, 2015; Ziafar \& Namaziandost, 2019).

\subsection{Empirical Background}

As a matter of fact, several empirical studies have been conducted about self-regulation and self-efficacy. Yusuf (2011) studied the relationship between self-efficacy, achievement motivation, and self-regulated learning strategies of not only undergraduate students, but also applying the limited structural equation modeling (SEM) in Malaysia. He investigated 300 undergraduate students using the Confirmatory Factor Analysis to find out if there was any correlation between self-efficacy beliefs, achievement motivation, and self-regulated learning strategies of the undergraduate students. As the study results showed, there was a considerable correlation between self-efficacy beliefs, achievement motivation, and self-regulated learning strategies (Namaziandost, Shatalebi, \& Nasri, 2019).

In another study, Woodrow (2011) conducted a research about self-efficacy and anxiety. The participants were 740 English college students from four universities in China. They filled out a self-efficacy and anxiety 7-point Likert scale questionnaire of English writing with semi-structural questions, and then completed a writing task. The Confirmatory Factor Analysis was used to analyze the data. Evidentially, self-efficacy was conformed to be a mediating construct among learners' language learning behavior and anxiety (Woodrow, 2011). As a conclusion, the results showed that it was more possible that students under stress experience much strain and try less in terms of English studying.

Furthermore, Kim, Wang, Ahn, and Bong (2015) investigated various structural rules of English as a Second Language (ESL) by means of the modern methodologies to analyze the profiles of the students in terms of their beliefs toward self-efficacy in the realm of English language learning. To this end, they surveyed a questionnaire of English selfefficacy, and the participants were Korean undergraduate students. The investigation presented low, medium, and high levels of self-efficacy among students' profiles. Those students with high and medium levels of self-efficacy in their profiles were mostly females had a long history in learning English language.

Due to the fact that there has been done no particular research on the relationship between learning belief and selfregulation in an online English language learning setting. Zheng, Liang, Yang, and Tsai (2016) conducted a research. They developed two discrete questionnaires: Conceptions of Learning English (COLE) and Online Self-regulated English Learning (OSEL) concerning the relationship between the learning beliefs and online self-regulation of 400 university students in China. They found that learners' COLE and OSEL were quite linked so that the relationship between online self-regulation and learners' belief were significant.

Yet, in another empirical study, Anam and Stracke (2016) examined the variety of self-regulated learning strategies among 520 Indonesian elementary school students. The questionnaires were: Strategy Inventory for Language Learning (SILL) and Self-efficacy in Learning English (C-SELEQ) for Indonesian children. The participants' results showed that they were more likely to use socio-affective and metacognitive than cognitive strategies. It revealed that young students were much happier if they could study in class settings and group instructional environments than rote memorization in isolation. The students' results also showed that they use strategies differently.

More recently, Su, Zheng, Liang, and Tsai (2018) surveyed the relationship between online self-regulation and selfefficacy of 420 Chinese university students in an EFL instructional setting. They used two questionnaires to gather information: The online self-regulated English learning (OSEL) and the English language self-efficacy (ELSE). In particular, the OSEL questionnaire consisted of six categories: goal setting, environment structuring, task strategies, time management, help seeking, and self-evaluation. In addition, the ELSE questionnaire included four language learning skills: Listening, speaking, reading, and writing. In addition, the data analysis indicated that the relationship between online self-regulated English learning and English language self-efficacy was confirmed through correlation analysis. Besides, based on regression analysis, self-evaluation was found to be the explanatory dominant predictor of self-efficacy variance of the different participants. Finally, it was concluded that the relationship between online selfregulation and self-efficacy was too complicated that any more empirical studies would be appreciated. 


\section{Methodology}

\subsection{Design of the Study}

Quantitative correlational design was used in this study. Accordingly, the study employs a correlational design to extract needed data of 120 undergraduate students. This study focused on the variable of self-regulation and selfefficacy which are hypothesized to be affected by each other.

\subsection{Participants}

The participants of this study were 120 undergraduate students who had been selected via non-random sampling (convenience sampling) from State and Azad universities in Ahvaz, Iran. The participants' age range was from 18 to 26. All of the participants were majoring in English language learning fields. It was not surprising that female students (75) outnumbered male students (30) in the current study because Iranian females would have higher tendency to request for this field than Iranian males. Unfortunately, a few numbers of participants remained unknown (15), and the gender of the participants was not considered to be measured. The reason behind choosing this number of participants was that the interpretation of the results from the questionnaires and interviews had been a hard and timeconsuming task. Thus, the findings would be interpreted and analyzed more accurately and significantly.

\subsection{Instruments}

To collect the required data on TEFL learners' English language self-regulation and self-efficacy, two questionnaires and an interview were used. The two questionnaires were designed to collect quantitative data, and it was adapted from previous validated questionnaires with acceptable reliability and validity. The interview then followed the questionnaires to collect qualitative data.

The first questionnaire, the questionnaire of English self-regulation (QESR), was adapted from the online selfregulated English learning questionnaire (Zheng et al., 2016) to evaluate self-regulation of Iranian TEFL undergraduate learners. The overall Cronbach's alpha value of the questionnaire, which had been widely accepted in terms of reliability and validity, was 0.91 .

Logically, we needed to make some modifications of the original instrument by adding a few new items, such as some word-removals, word-replacements, and minor grammatical corrections. The ultimate instrument to assess selfregulation of Iranian TEFL undergraduate learners consisted of 20 items, and a 7-point Likert scale with values ranging from 1 (I cannot do it at all) to 7 (I can do it well).

The second questionnaire, the questionnaire of English self-efficacy (QESE), was also adapted from the self-efficacy English learning questionnaire (Zheng, Su, \& Lian,_2014) to evaluate self-regulation of Iranian TEFL undergraduate learners. Originally, the reliability and validity were already been proved to be acceptable, the alpha coefficient was about $0.88-0.92$ with an approximately high level of internal consistency reliability $(\alpha=0.99)$.

Logically, we needed to make some modifications of the original instrument by adding a few new items, such as some word-removals, word-replacements, and minor grammatical corrections. The ultimate instrument to assess selfregulation of Iranian TEFL undergraduate learners consisted of 32 items, and a 7-point Likert scale with values ranging from 1 (I cannot do it at all) to 7 (I can do it well).

According to the fact that the previous studies mentioned in the literature had mostly been done in the quantitative manners, however, the qualitative aspects were worth taking into account as well. Hence, an interview was needed to be designed and included as the third instrument of the current study. The interview was semi-structured and had eight fully descriptive and explanatory questions. The researchers interviewed 10 participants who had already filled the questionnaires. They actually volunteered to do the interview and answer the questions in English language. The interview had continued until it was saturated.

\subsection{Data Collection Procedure}

To carry out the present study, total number of 120 participants with the age range of (18-26) from Ahvaz State and Azad universities were conveniently selected, all of whom were under-graduated students majoring in one of the English as a Foreign Language (EFL) learning fields including English teaching, English literature, and English translation. It was noted to say that since there were limited accessible undergraduate TEFL students in Ahvaz, other 
undergraduate English literature and translation were involved. Moreover, the gender discrimination of the participants was not considered in the present study.

Then, the participants were asked to answer the QESR and QESE questionnaires in the classroom environments or the college campuses. Needless to say that the participants were informed of the anonymous nature of the data collection process in advance. They were also told that their responses would certainly be kept confidential and that they had the right to quit at any part of the survey. It took around 15-20 minutes for each respondent to complete the survey. After that, only a few participants felt capable and courageous enough to willingly volunteer for the interview and answer the interview questions efficiently.

\subsection{Data Analysis}

Collected data through the above-stated instruments were analyzed and interpreted according to the objectives of the study. Pearson Correlation Coefficients were calculated. It will be utilized to analyze the data and provide a logical answer for the question of "whether there is any significant relationship between English as foreign language learners" self-regulation and their self-efficacy."

\section{Results}

In order to analyze the gathered data, the SPSS (Statistical Package for Social Science) software was used.

Table 1. One-sample Kolmogorov-Smirnov test (self-efficacy and self-regulation questionnaires)

\begin{tabular}{llll}
\hline & & Self-efficacy & Self-regulation \\
\hline $\mathrm{N}$ & Mean & 120 & 120 \\
Normal Parameters & & 140.5000 & 139.5000 \\
& Std. Deviation & 28.04109 & 26.56370 \\
& Absolute & .207 & .192 \\
Most Extreme Differences & Positive & .207 & .192 \\
& Negative & -.157 & -.156 \\
Kolmogorov-Smirnov Z & & 2.269 & 2.109 \\
Asymp. Sig. (2-tailed) & & .542 & .489 \\
\hline
\end{tabular}

a. Test distribution is Normal.

b. Calculated from data.

Table 1 shows that the statistics of scores are normal as the results obtained from using SPSS 22. In this case, the parametric statistics like Pearson correlation coefficient can be used to get the final results. As the first research question aims to check if there a significant relationship between Iranian undergraduate TEFL learners' self-regulation and their self-efficacy, correlation coefficients between the scores of self-efficacy and self-regulation questionnaires were checked.

Table 2. Descriptive statistics of self-efficacy and self-regulation questionnaires

\begin{tabular}{llll}
\hline & Mean & Std. Deviation & N \\
\hline Self-efficacy & 140.5000 & 28.04109 & 120 \\
Self-regulation & 139.5000 & 26.56370 & 120 \\
\hline
\end{tabular}

As Table 2 shows that the mean and standard deviation of the participants' scores on the self-efficacy questionnaire were 140.50 and 28.04, respectively. Table 2 also shows the mean and standard deviation of the participants' scores 
on the self-regulation questionnaire were 139.50 and 26.56, respectively. To ascertain if there is a positive relationship between self-efficacy and self-regulation of the participants, Pearson correlation coefficient was used (Table 3).

Table 3. Correlation coefficients between the scores of self-efficacy and self-regulation questionnaires

\begin{tabular}{llll}
\hline & & Self-efficacy & Self-regulation \\
\hline Self-efficacy & Pearson Correlation & 1 & $.975^{* *}$ \\
& Sig. (2-tailed) & & .000 \\
& $\mathrm{~N}$ & 120 & 120 \\
Self-regulation & Pearson Correlation & $.975^{* *}$ & 1 \\
& Sig. (2-tailed) & .000 & \\
& $\mathrm{~N}$ & 120 & 120 \\
\hline
\end{tabular}

**. Correlation is significant at the 0.01 level (2-tailed).

As shown in Table 3, the results of two-tailed Pearson correlation analysis revealed a significant and strong relationship between the participants' scores on self-efficacy and self-regulation questionnaires $(r=0.975, p<.000)$. The Cohen's (1988) criterion for interpreting the strength of correlation was followed. Cohen (1988) asserted that correlation coefficient of more than 0.50 is strong.

After analyzing the interview qualitatively, it was revealed that students were eager to use stories in English language to be exposed to language learners to English language in Iran. Through this, their self-efficacy will definitely improve. Students also believed that using moderately- difficult tasks is another way to enhance self-efficacy. If the task is too easy will be boring or embarrassing and may communicate the feeling that the teacher doubts their abilities; a toodifficult task will re-enforce low self-efficacy. The target for difficulty is slightly above the students' current ability level.

Moreover, they believed that they can learn by watching a peer succeed at a task. Peers may be drawn from groups as defined by gender, ethnicity, social circles, interests, achievement level, clothing, or age. Encourage students to try was another factor the students claimed to progress their self-efficacy. It means that teachers should give them consistent, credible, and specific encouragement, such as, "You can do this. We've set up an outline for how to write a lab report and a schedule for what to do each week - now follow the plan and you will be successful."

In addition, the teachers are recommended to giving praise and encouragement is very important, however it must be credible. Use praise when earned and avoid hyperbole. When giving feedback on student performance, compare to past performances by the same student, don't make comparisons between students. The last factor was encouraging accurate attributions. It means that the teachers must help students understand that they don't fail because they're dumb, they fail because they didn't follow instructions, they didn't spend enough time on the task, or they did not follow through on the learning strategy.

\section{Discussion}

After conducting different analyses, the answers of the research questions were obtained. Therefore, the questions of the study have been answered below.

RQ1. Is there a significant relationship between Iranian Undergraduate TEFL learners' self-regulation and their selfefficacy?

The null hypothesis of the present study "There is a positive relationship between self-regulation and self-efficacy of Iranian undergraduate TEFL Learners" was supported. The findings of this study revealed that there was a significant relationship between self-regulation and self-efficacy of Iranian undergraduate TEFL learners. As Li and Wang (2010) claimed, those Chinese TEFL students with a high self-efficacy were more willing to frequently accomplish selfregulated strategies for reading. In a similar vein, another research among Korean university students indicated that 
different levels of self-efficacy would absolutely influence learners' performance in terms of applying self-regulated learning strategies (Kim et al., 2015; Namaziandost, Hashemifardnia, \& Shafiee, 2019). Still another research which measured the relationship between self-regulated strategy use and self-efficacy beliefs of Indonesian students confirmed the significance of such an interplay among self-regulation and self-efficacy of young learners (Anam \& Stracke, 2016; Namaziandost \& Ahmadi, 2019).

The results of this study were indeed in line with $\mathrm{Li}$ and Wang (2010) who examined the accordance of Chinese students' self-efficacy and their self-regulation which would potentially enhance English language learning. It was proved that so self-efficacious learners reached to more achievement in their learning processes. They also showed more success in problem-solving situations and challenging tasks, and they tended more to benefit from self-regulated strategies use for reading goals and learning progress. Moreover, the findings of the study were in line with Yusuf (2011) who studied the relationship between self-efficacy and self-regulated learning in terms of achievement and motivation of learning. He did his survey among Malaysian undergraduate students to figure out that there was a definite correlation between self-efficacy beliefs and self-regulated learning strategies use regarding learning achievement and motivation. The current study was also supported by Wang, Schwab, Fenn, and Chang (2013) who empirically researched into self-efficacy and self-regulation among Chinese and German college students. As the study results showed, there was a considerable correlation between self-efficacy and self-regulated learning strategies.

Likewise, this study compatibly led to what Ghonsooly and Ghanizadeh (2013) investigated the relationship between Iranian TEFL learners' self-efficacy beliefs and self-regulated language learning strategies use. Furthermore, the findings were agreed with Los' (2014) investigation around the mediating effect of self-regulation on self-efficacy and academic outcome. The results of the current study were significantly in accordance with Su et al. (2018) who recently carried out the research on the relationship between online self-regulation and self-efficacy among Chinese university students. Alike, they applied almost the same two questionnaires for the purpose of data collection on online self-regulation and self-efficacy. Although it was supported that self-regulation and self-efficacy had genuinely a positive coordination, it was also obvious that more empirical studies were needed for more supports (Namaziandost, Neisi, Kheryadi, \& Nasri, 2019).

Thus, those learners with a stronger sense of self-efficacy can generally be more self-regulated in learning. Similarly, learners who tended more to employ self-regulated language learning skills displayed to have deeper confidence on their self-efficacy beliefs, thoughts, and instinctive learning style as well. This result is also in compatible with prior studies indicating the positive connection among self-regulation and self-efficacy (Namaziandost, Hosseini, \& Utomo, 2020; Yusuf, 2011). Therefore, as the results echoed, students with strong self-efficacy beliefs have normally more inclination to apply self-regulated language learning strategies and processes, and inversely students with strong selfregulated strategies demonstrate more natural tendency toward self-efficacy beliefs (Namaziandost \& Shafiee, 2018; Zimmerman \& Cleary, 2006).

RQ2. What predictive role does Iranian Undergraduate TEFL learners' self-regulation play on their self-efficacy?

It was consequently understood from the results of the interview that the more learners get to know about their personal abilities, skills, and characteristics, they would be more successful in their process of learning. As learners enhance their knowledge of self-efficacy beliefs, they become skillfully capable to regulate and control challengeable activities in the realm of language learning. Highly self-efficacious students are more willing to use self-regulated strategies and tasks in the learning process. In the other words, they are more active and better participants in the difficult problem-solving situations.

The findings of the present study are also consistent with current empirical research, although most studies investigating the interplay of self-regulation and self-efficacy have addressed their mediating roles in academic achievement or on other motivational variables. Zimmerman (2000), for example, states that when studied as a mediating variable in training studies, self-efficacy has proven to be responsive to improvements in students' methods of learning (especially those involving greater self-regulation) and predictive of achievement outcomes. Similarly, Pintrich and De Groot (1990) and Kitsantas (2000) found a positive relationship between self-efficacy and metacognitive strategy use which produces successful performance outcomes. Zimmerman, Bandura, and MartinezPons (1992) revealed that the interaction between perceived self-efficacy and metacognitive strategy use accounted for about 30\% variability in learners' academic performance. Bembenutty (2007), meanwhile, reported that teachers' self-efficacy beliefs influence their academic performance, which is mediated by their use of self-regulatory learning strategies. 


\section{Conclusion}

From a linguistic perspective, learning a foreign language could be really a complicated process in which selfregulation and self-efficacy are crucially included as the two fundamentally interactive psychological constructs. According to Bandura (1977), self-efficacy beliefs were assumed to directly develop choices of learning activities and contexts. In the other words, self-efficacious learners could adjustably imitate the needed effort through contextualized substitutions of language learning approaches. Moreover, Zimmerman and Kitsantas (2014) believed that learners could reach to better achievements by means of the application of self-regulated various learning strategies. Ultimately, it was concluded from the findings of the current study that the delicate association between self-regulation and self-efficacy was really helpful for learners to lead them successfully to their academic goals. Therefore, it was absolutely the result of such a significant positive close relationship between self-regulation strategies use and selfefficacy beliefs that the learning process would become much more enjoyable for students to feel the vital demand to engage in very difficult problem-solving situations and complex challenging settings of learning, hence persist longer.

\section{References}

Aghajani, M. (2018). Types of intelligences as predictors of self-efficacy: A study on Iranian EFL students. International Journal of Research in English Education (IJREE), 3(4), 12-26.doi: 10.29252/ijree.3.4.12 http://ijreeonline.com/article-1-114-en.html

Anam, S., \& Stracke, E. (2016). Language learning strategies of Indonesian primary school students: In relation to self-efficacy beliefs. System, 60, 1-10. https://doi.org/10.1016/j.system.2016.05.001

Bandura, A. (1982). Self-efficacy mechanism in human agency. Journal of American Psychologist, 37(2), $122-147$. https://doi.org/10.1037/0003-066X.37.2.122

Bandura, A. (1986). Social foundations of thought and action: A social cognitive theory. Englewood Cliffs, NJ: Prentice-Hall.

Bandura, A. (1991). Social cognitive theory of self-regulation. Organizational Behavior and Human Decision Processes, 50(2), 248-287. https://doi.org/10.1016/0749-5978(91)90022-L

Bandura, A. (1993). Perceived self-efficacy in cognitive development and functioning. Journal of Educational Psychologist, 28(2), 117-48. https://www.uky.edu/ eushe2/Bandura/Bandura1993EP.pdf Accessed 3 September 2020.

Bandura, A. (1997). Self-efficacy: The exercise of control. New York: W. H. Freeman and Company.

Bembenutty, H. (2007). Self-regulation of learning and academic delay of gratification: Gender and ethnic differences among College students. Journal of Advanced Academics, 18(4), 586-616. https://doi.org/10.4219/jaa-2007$\underline{553}$

Boekaerts, M., \& Cascallar, E. (2006). How far have we moved toward the integration of theory and practice in self-regulation? Educational Psychology Review, 18, 199-210. http://dx.doi.org/10.1007/s10648-006-9013$\underline{4}$

Cohen J. (1988). Statistical power analysis for the behavioral sciences. New York, NY: Routledge Academic.

Dignath, C., Büttner, G., \& Langfeldt, H. P. (2008). How can primary school students acquire self-regulated learning most efficiently? A meta-analysis on interventions that aim at fostering self-regulation. Educational Research Review, 3(2), 101-129. doi: 10.1016/j.edurev.2008.02.003

Dornyei, Z. (2005). The psychology of the language learner: Individual differences in second language acquisition. Hillsdale, NJ: Lawrence Erlbaum Associates.

Dörnyei, Z., \& Ryan, S. (2015). The psychology of the language learner revisited. New York, NY: Routledge.

Ghonsooly, B., \& Ghanizadeh, A. (2013). Self-efficacy and self-regulation and their relationship: A study of Iranian EFL teachers. The Language Learning Journal, 41(1), 68-84. http://dx.doi.org/10.1080/09571736.2011.625096 
Etemadfar, P., Namaziandost, E., \& Banari, R. (2019). The impact of different output-based task repetition conditions on producing speech acts among Iranian advanced EFL learners. Theory and Practice in Language Studies, 9(12), 1541-1549. doi: $10.17507 /$ tpls.0912.10

Hashemifardnia, A., Namaziandost, E., \& Shafiee, S. (2018). The effect of implementing flipped classrooms on Iranian junior high school students' reading comprehension. Theory and Practice in Language Studies, 8(6), 665-673. doi: $\underline{10.17507 / \text { tpls.0806.17 }}$

Kim, D. H., Wang, C., Ahn, H. S., \& Bong, M. (2015). English language learners' self-efficacy profiles and relationship with self-regulated learning strategies. Learning \& Individual Differences, $38, \quad 136-142$. https://doi.org/10.1016/j.lindif.2015.01.016

Kitsantas, A. (2000). The role of self-regulation strategies and self-efficacy perceptions in successful weight loss maintenance. Psychology \& Health: An International Journal, 15(6), 811-820. doi: $\underline{10.1080 / 08870440008405583}$

Lam, R. (2014). Promoting self-regulated learning through portfolio assessment: testimony and recommendations. Assessment \& Evaluation in Higher Education, 39(6), 699-714. doi: $\underline{10.1080 / 02602938.2013 .862211}$

Li, Y., \& Wang, C. (2010). An empirical study of reading self-efficacy and the use of reading strategies in the Chinese EFL context. Asian EFL Journal, 12(2), 144-162. https://www.asian-efljournal.com/771/quarterlyjournal/2010/06

Liu, S. H. J., Lan, Y. J., \& Ho, C. Y. Y. (2014). Exploring the relationship between self-regulated vocabulary learning and web-based collaboration. Journal of Educational Technology \& Society, 17(4), 404-419.

Los, R. (2014). The effects of self-regulation and self-efficacy on academic outcome. United States: ProQuest LLC. https://www.researchgate.net/publication/269106120

Namaziandost, E., \& Shafiee, S. (2018). Gender differences in the use of lexical hedges in academic spoken language among Iranian EFL learners: a comparative study. International Journal of Research in English Education, 3(4), 64-80. doi: 10.29252/ijree.3.4.63 http://ijreeonline.com/article-1-130-en.html

Namaziandost, E., \& Ahmadi, S. (2019). The assessment of oral proficiency through holistic and analytic techniques of scoring: A comparative study. Applied Linguistics Research Journal, 3(2), 70-82. https://www.journalagent.com/alrj/pdfs/ALRJ_3 2 70_82.pdf Accessed 3 September 2020.

Namaziandost, E., \& Çakmak, F. (2020). An account of EFL learners' self-efficacy and gender in the flipped classroom model. Education and Information Technologies, 25(2). https://doi.org/10.1007/s10639-020-101677

Namaziandost, E., Hashemifardnia, A., \& Shafiee, S. (2019). The impact of opinion-gap, reasoning-gap, and information-gap tasks on EFL learners' speaking fluency. Cogent Social Sciences, 5, 1630150. https://doi.org/10.1080/23311886.2019.1630150

Namaziandost, E., Hosseini, E., \& Utomo, D. W. (2020). A comparative effect of high involvement load versus lack of involvement load on vocabulary learning among Iranian sophomore EFL learners. Cogent Arts and Humanities, 7(1), 1-15. https://doi.org/10.1080/23311983.2020.1715525

Namaziandost, E., Neisi, L., Kheryadi., \& Nasri. M. (2019). Enhancing oral proficiency through cooperative learning among intermediate EFL learners: English learning motivation in focus. Cogent education, 6, 1683933. https://doi.org/10.1080/2331186X.2019.1683933

Namaziandost, E., Nasri, M., \& Ziafar, M. (2019). Comparing the impacts of various inputs (I+1 \& I-1) on preintermediate EFL learners' reading comprehension and reading motivation: the case of Ahvazi learners. Asian. J. Second. Foreign. Lang. Educ., 4(13), 1-20. doi:10.1186/s40862-019-0079-1

Namaziandost, E., Pourhosein Gilakjani, A., \& Hidayatullah (2020). Enhancing pre-intermediate EFL learners' reading comprehension through the use of Jigsaw technique. Cogent Arts \& Humanities, 7(1), 1-15. https://doi.org/10.1080/23311983.2020.1738833 
Namaziandost, E., Rezvani, E., \& Polemikou, A. (2020). The impacts of visual input enhancement, semantic input enhancement, and input flooding on L2 vocabulary among Iranian intermediate EFL learners. Cogent Education, 7(1). doi: 10.1080/2331186X.2020.1726606

Namaziandost, E., Shatalebi, V., \& Nasri, M. (2019). The impact of cooperative learning on developing speaking ability and motivation toward learning English. Journal of Language and Education, 5(3), 83-101. https://doi.org/10.17323/jle.2019.9809

Niloufari, R., \& Dastgoshadeh, A. (2019). Possible selves as correlates of EFL teachers' self-efficacy and students' achievement. International Journal of Research in English Education (IJREE), 4(4), 13-26. doi: 10.29252/ijree.4.4.13 http://ijreeonline.com/article-1-236-en.html

Pajares, F. (2009). Motivational role of self-efficacy beliefs in self-regulated learning. In D. H. Schunk, \& B. J. Zimmerman (Eds.), Motivation and self-regulated learning: Theory, research, and applications (pp. 111-139). New York, NY: Routledge.

Pajares, F., \& Usher, E. L. (2008). Self-efficacy for self-regulated learning: a validation study. Educational and Psychological Measurement, 68(3), 443e463. http://dx.doi.org/10.1177/0013164407308475

Pintrich, R. R., \& DeGroot, E. V. (1990). Motivational and self-regulated learning components of classroom academic $\begin{array}{lllll}\text { performance. Journal of } & \text { Educational }\end{array}$ http://dx.doi.org/10.1037/0022-0663.82.1.33

Schunk, D. H. (1984). Self-efficacy perspectives on achievement behavior. Journal of Educational Psychologist, 19(1), 48-58. doi: $\underline{10.1080 / 00461528409529281}$

Schunk, D. H., \& Meece, J. L. (2006). Self-Efficacy development in adolescence. In F. Pajares, \& T. Urdan (Eds), Self-efficacy beliefs of adolescents (pp. 71-96). Greenwich, CT: Information Age.

Su, Y., Zheng, C., Liang, J., \& Tsai, C. (2018). Examining the relationship between English language learners' online self-regulation and their self-efficacy. Australasian Journal of Educational Technology, 34(3), 22-45. https://doi.org/10.14742/ajet.3548

Wang, C., Schwab, G., Fenn, P., \& Chang, M. (2013). Self-efficacy and self-regulated learning strategies for English language learners: Comparison between Chinese and German college students. Journal of Educational and Developmental Psychology, 3(1), 173-191. http://dx.doi.org/10.5539/jedp.v3n1p173

Woodrow, L. (2011). College English writing affect: Self-efficacy and anxiety. System, 39(4), 510-522. http://dx.doi.org/10.1016/j.system.2011.10.017

Yusuf, M. (2011). The impact of self-efficacy, achievement, motivation, and self-regulated learning strategies on students' academic achievement. Procedia Social and Behavioral Sciences, $\quad 15, \quad 2623-2626$. https://doi.org/10.1016/j.sbspro.2011.04.158

Zeidner, M., Boekaerts, M., \& Pintrich, P. R. (2000). Self-regulation: Directions and challenges for future research. In M. Boekaerts, P. R. Pintrich, \& M. Zeidner (Eds.), Handbook of self-regulation (pp. 49-68). San Diego, CA: Academic Press.

Zheng, C., Liang, J. C., Yang, Y. F., \& Tsai, C. C. (2016). The relationship between Chinese university students' conceptions of language learning and their online self-regulation. System, 57, 66-78. https://doi.org/10.1016/j.system.2016.01.005

Zheng, C., Su, Y., \& Lian, J. (2014). Developing an online formative assessment system for a Chinese EFL course. In Y. T. Wu, T. Supnithi, T. Kojiri, C. C. Liu, H. Ogata, S. C, Kong, \& A. Kashihara (Eds.), Proceedings of the 22nd International Conference on Computers in Education (pp. 532-535). Nara: Asia Pacific Society for Computers in Education.

Ziafar M., \& Namaziandost, E. (2019). Linguistics, SLA and lexicon as the unit of language. International Journal of Linguistics, Literature and Translation (IJLLT), 2(5), 245-250. doi: 10.32996/ijllt.2019.2.5.29 http://www.ijllt.org/linguistics-sla-and-lexicon-as-the-unit-of-language/ 
Ziegler, N. A. (2014). Fostering self-regulated learning through the European language portfolio: An embedded mixed methods study. The Modern Language Journal, 98(4), 921-936. https://doi.org/10.1111/modl.12147

Ziegler, N. A., \& Moeller, A. J. (2012). Increasing self-regulated learning through the lingua-folio. Foreign Language Annals, 45(3), 330-348. doi: 10.1111/j.1944-9720.2012.01205.x

Zimmerman, B. J. (1989). A social cognitive view of self-regulated academic learning. Journal of Educational Psychology, 81(3), 329-339. https://doi.org/10.1037/0022-0663.81.3.329

Zimmerman, B. J. (1990). Self-regulated learning and academic achievement: an overview. Educational Psychologist, 25(1), 3-17. https://doi.org/10.1207/s15326985ep2501_2

Zimmerman, B. J. (2000). Attaining self-regulation: A social cognitive perspective. In M. Boekaerts, P. R. Pintrich, \& M. Zeidner (Eds.), Handbook of self-regulation (pp. 13-39). San Diego, CA: Academic Press.

Zimmerman, B. J., Bandura, A., \& Martinez-Pons, M. (1992). Self-motivation for academic attainment: The role of self-efficacy beliefs and personal goal setting. American Educational Research Journal, 29(3), 663-676. https://doi.org/10.3102/00028312029003663

Zimmerman, B. J., \& Cleary, T. J. (2006). Adolescents' development of personal agency: The role of self-efficacy beliefs and self-regulatory skill. In F. Pajares, \& T. Urdan (Eds.), Self-efficacy beliefs of adolescents (pp. 4569). Greenwich, CT: Information Age Publishing.

Zimmerman, B. J., \& Kitsantas, A. (2014). Comparing students' self-discipline and self-regulation measures and their prediction of academic achievement. Contemporary Educational Psychology, 39(2), 145-155. https://doi.org/10.1016/j.cedpsych.2014.03.004

Zimmerman, B. J., \& Risemberg, R. (1997). Becoming a self-regulated writer: A social cognitive perspective. Contemporary Educational Psychology, 22(1), 73-101. https://doi.org/10.1006/ceps.1997.0919

Zimmerman, B. J., \& Schunk, D. H. (Eds.). (1989). Self-regulated learning and academic achievement: Theory, research, and practice. New York: Springer Verlag.

Zimmerman, B. J., \& Schunk, D. H. (2011). Self-regulated learning and performance: An introduction and overview. In B. J. Zimmerman, \& D. H. Schunk (Eds.), Handbook of self-regulation of learning and performance (pp.115). New York, NY: Routledge Press. 